\title{
GRM2 Gene
}

National Cancer Institute

\section{Source}

National Cancer Institute. GRM2 Gene. NCI Thesaurus. Code C114526.

This gene plays a role in the inhibition of adenylate cyclase signaling. 